\title{
German parties compete for scientists' vote
}

Bonn. Germany's ruling conservative coalition of Christian Democrats (CDU) and Free Democrats (FDP) is still odds-one favourite to retain power after the general elections on 16 October. But, whatever the outcome, the chances of a significant change in German scientific research policy are low.

Both the CDU and its main rival, the Social Democrats (SPD) - who could join a coalition with the CDU, with the FDP and the Greens, or even (though less likely), with the Greens alone - are committed to maintaining the strength of German science. The main difference is that the SPD is offering more money (in particular for applied research), while the CDU is holding out for less regulation of researchers.

Both parties want to improve the application of scientific results to new technological developments, and have plans for widening the dialogue between researchers and industry. Both strongly support further development of key technologies such as information and biotechnologies.

Both also agree that research spending by the government should be strictly controlled - which probably means no shift in Germany's uncompromising position that all annual subscriptions to large international research programmes, such as the European Laboratory for Particle Physics (CERN), should be kept constant in real terms. But both are strongly in favour of international research collaboration as a means of sharing the costs of expensive programmes and facilities.

There are some small but significant differences in emphasis. Although it no longer talks of massive funding for solar energy research, for example, the SPD clearly favours socially orientated research programmes, such as health research. In contrast, the CDU is more enthusiastic about industrially orientated research programmes, such as aerospace technologies.

In addition, the parties diverge significantly on two major programmes, both in the planning stage. Because of concern about nuclear proliferation, the SPD would not allow the controversial FRM-II research reactor at the Technical University of Munich to burn highly enriched uranium, as it has been designed to do.

Nor would the SPD back Germany's bid to host the next-generation fusion reactor, the International Thermonuclear Experimental Reactor (ITER), whose estimated costs it regards as excessive.

Overall the SPD has promised that, if elected, it would increase the federal research budget by DM1 billion, bringing it back to the level of the mid-1980s. The party has not said where this money will come from. But Josef Vosen, science spokesman for the parliamentary SPD fraction, says it would be spent on applied research, on the

grounds that basic research in Germany is already well catered for.

In contrast, the CDU has no plans to increase research funding, preferring to concentrate on improving the efficiency with which research funds are used. There is indeed some difference between the two major parties in their views on the appropriate level of regulation of research.

Many German researchers complain about the amount of paperwork they are required to complete, for example when

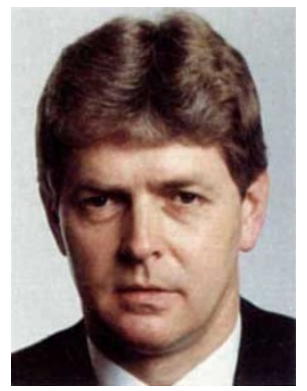
applying for permission to do genetic experiments or to work with animals or radioactivity. Responding to such complaints, the CDU is promising to reduce controls on researchers in order to create a more supportive research environment.

Krüger: unlikely to remain minister.

The SPD claims that it wants to do the same. But, given the tensions between the pragmatic parliamentary fraction of the party in Bonn and the more ideological Länderlevel groups, its actual position is less clearcut. Wolf-Michael Catenhusen, head of the parliamentary committee on research, says the need is to maintain regulation while reducing form-filling, and Vosen talks of the need to "de-bureaucratize" laws governing research in genetic engineering.

But the Institute of German Economy, a free-market-orientated think-tank, considers that in practice the SPD will allow ethics committees to increase their influence over researchers, making it harder to reduce the amount of red tape.

In contrast, the SPD may be better placed than the CDU to introduce tax incentives for industrial research. Both parties are in favour of such incentives. But the finance minister in the current CDU/FDP coalition government has consistently resisted the idea. An SPD-influenced government may push it through faster.

Even if the CDU remains in power, it is unlikely that Paul Krüger, from east Germany, will continue as research minister, as he would probably fall victim to demands on the new government for geographical representation.

Chancellor Helmut Kohl has said that he wants a "leaner government" after the election, with a merging of smaller ministries. This would mean fewer ministerial positions at a time when three of the five new Länder in the former East Germany are likely to vote heavily for Kohl, and will expect to be rewarded.

At present, the cabinet has only two east German ministers, both from the state of Mecklenburg-Vorpommern, Angela Merkel, the only woman in the cabinet. Thus Krüger (though not necessarily the research ministry) will almost certainly have to give way to a candidate from either Saxony or Thüringen.

If the FDP fails, as many predict, to reach the 5 per cent of votes required to secure seats in parliament, the chances of a 'redgreen' coalition will be higher. Whether researchers should be worried will depend on how the ministries are divided up.

In such a situation, the research ministry would almost certainly go to Peter Glotz, a veteran SPD politician but an unknown quantity as far as science and research are concerned. Better known is the Hessen environment minister, Joschka Fischer, a leading member of the Greens and a strong candidate for federal environment minister.

The flamboyant Fischer has sparked controversy locally: for example, he successfully blocked the building of a production plant for mixed-oxide fuel elements for nuclear reactors (see Nature 369, 6; 1994), and introduced speed limits in high-ozone conditions (see Nature 370, 321; 1994). He would probably find his influence considerably diluted at federal level, and 'red-green' is probably not as threatening for science as it is often made out to be. Alison Abbott

\section{Israel set to join EC Framework programme}

London. Israel's scientific community took a step closer to their goal of becoming full participants in European-level research programmes with the decision last week of research ministers of the 12 European Union member states to agree on a negotiating mandate towards this goal.

The mandate established the terms of a broad scientific agreement between Israel and the European Commission in Brussels. Under the terms of such a magnate, the Israeli government would agree to contribute to the ECU12.0 billion (US\$13.6 billion) Fourth Framework Research Programme.

In return, Israeli scientists would be able to become fully associated with all non-nuclear research programmes under the Framework programme. The agreement will enable Israeli research teams to participate in a wide range of research areas, including biotechnology, renewable energies, biomedicine and advanced materials. 